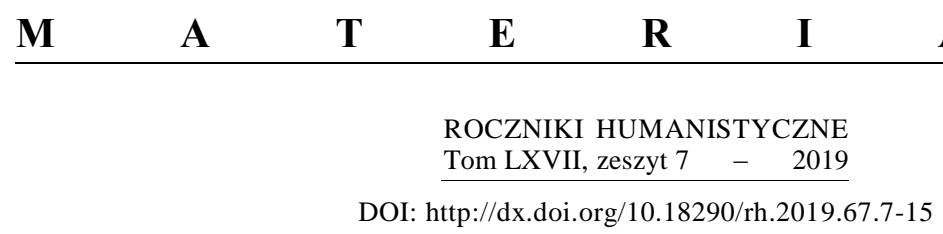

MARTA KACZMARCZYK

\title{
UMYSŁ NIE ZNIEWOLONY. O ZAINTERESOWANIACH NAUKOWYCH PROFESOR STEFANII ANDRUSIW
}

W roku 2019 KUL-owska slawistyka obchodzi jubileusz 30-lecia swojego istnienia. Ten okres obfitował w wiele inicjatyw i wydarzeń, które wyraźnie zapisały się $\mathrm{w}$ rozwoju slawistyki polskiej. Nieocenione zasługi prof. Ryszarda Łużnego - kreatora i założyciela ośrodka lubelskiego (Międzywydziałowy Zakład Badań nad Kulturą Bizantyjsko-Słowiańską, działający od roku 1981) - dały podwaliny, na których, z biegiem lat, powstała prężnie działająca jednostka badawcza - Instytut Filologii Słowiańskiej KUL. Obecnie mija 30 lat od utworzenia i uruchomienia pierwszego roku studiów na kierunku Filologia Słowiańska (1989). W ciągu tego czasu Instytut opuściła nie tylko szeroka rzesza absolwentów, ale, co warto podkreślić, z KUL-owskim ośrodkiem slawistycznym związane było zacne grono pracowników naukowych, do którego przez ponad dziesięć lat należała prof. Stefania Andrusiw - wybitna uczona, literaturoznawca, kulturolog i ukraiński krytyk literacki, autorka licznych artykułów naukowych, publikowanych w polskich, ukraińskich, niemieckich czasopismach naukowych i pracach zbiorowych, recenzent i członek postępowań w przewodach doktorskich i habilitacyjnych, członek różnych

Dr MARTA KACZMARCZYK - adiunkt Katedry Literatury Ukraińskiej i Białoruskiej w Instytucie Filologii Słowiańskiej KUL; e-mail: mreda@kul.lublin.pl; ORCID 0000-0002-8840-5509 
komitetów i towarzystw naukowych, w tym m.in. Związku Pisarzy Ukraińskich.

Badaczka ukraińska rozpoczęła pracę w Instytucie Filologii Słowiańskiej w 2001 roku na stanowisku profesora nadzwyczajnego w istniejącej wówczas Katedrze Literatur Wschodniosłowiańskich. W roku akad. 2005/2006 w Instytucie utworzono Katedrę Literatury Ukraińskiej. Jej kierownikiem została prof. Andrusiw, która aktywnie zaangażowała się w rozwój i upowszechnienie studiów ukrainistycznych w Polsce oraz we współpracę i dialog polsko-ukraiński. Profesor pracowała w Instytucie do 2013 roku. W tym czasie podejmowała różne inicjatywy i wyzwania zarówno naukowe, jak i dydaktyczne. Co się tyczy dydaktyki, prowadziła bardzo interesujące wykłady $\mathrm{z}$ historii literatury ukraińskiej, głównie XX i początku XXI wieku, które cieszyły się dużą popularnością wśród studentów, i nie jest to z mojej strony przesadna kurtuazja czy swego rodzaju hiperbola, mająca na celu gloryfikację Jej dokonan; rzeczywiście tak było. Pani Profesor była naukowcem i dydaktykiem z powołania, a przedmiot, którym się zajmowała - literatura ukraińska była wielką Jej pasją, co więcej, jak sama mawiała - miłością. Profesjonalne podejście, pełne oddanie i ogromne zaangażowanie imponowały, co zrozumiałe, studentom, ale również współpracownikom. W dorobku dydaktycznym Profesor znajdowały się również seminaria magisterskie oraz doktoranckie. W trakcie pracy w KUL wypromowała bardzo liczne grono magistrów, wykształciła również, co warto podkreślić, 12 doktorów, większość z nich związała się na stałe z nauką.

Od samego początku pracy w KUL prof. Andrusiw była członkiem Rady Wydziału Nauk Humanistycznych. Angażowała się również w prace innych gremiów naukowych. Była członkiem Rady Naukowej „Roczników Humanistycznych" (seria: Słowianoznawstwo), komitetu redakcyjnego czasopisma „Studia Ucrainica Varsoviensia”; współpracowała z lubelskim oddziałem Komisji Polsko-Ukraińskich Związków Kulturowych PAN, jednocześnie kontynuując współpracę z wydawanym przez Lwowską Akademię Sztuki czasopismem „Visnyk L'vivs'koyi naukovoyi akademiyi mystetsv” oraz miesięcznikiem literackim „Dzvin”.

W trakcie pracy w KUL Pani Profesor dała się poznać nie tylko jako kompetentny naukowiec, cieszący się uznaniem i autorytetem w środowisku naukowym, ale również, a może przede wszystkim, jako człowiek niezwykle pracowity, jednocześnie uczciwy i skromny; stroniła od pochwał i zaszczytów, wierzyła i służyła ideałom, nie lubiła poplecznictwa, karierowiczostwa, wszelkiej maści kombinatorstwa i układów, również w nauce. W tym kontekście bardzo imponowało Jej polskie środowisko naukowe. Cieszyła się, że pracuje w Pol- 
sce, w Lublinie, jednak miała świadomość kosztów, które za to ponosi. Chodzi przede wszystkim o wyobcowanie z ukraińskiego naukowego świata i dyskursu, które, po części, starała się kompensować, publikując teksty w ukraińskich czasopismach naukowych. Dzięki pobytowi w Polsce zyskała jednak potrzebną perspektywę i dystans, by bez zbędnych emocji oceniać kondycję literatury, literaturoznawstwa oraz Ukrainy, co chętnie czyniła.

Wieloletnia, bliska znajomość z prof. Andrusiw pozwoliła mi bardzo dobrze poznać Ją jako naukowca, ale również jako osobę prywatną. Wielokrotnie byłam świadkiem i uczestnikiem Jej życia zawodowego i osobistego, rozmów na temat fascynacji i inspiracji naukowych, narracji kulturologicznych czy historii rodzinnych. Jednak, kiedy po raz pierwszy zmierzyłam się z zadaniem przybliżenia sylwetki prof. Stefanii Andrusiw dla potrzeb projektu, jakim była publikacja Jej biogramu w Encyklopedii 100-lecia KUL [Kaczmarczyk 14], zdałam sobie sprawę, jak niewiele konkretnych informacji posiadam na Jej temat. To uświadomiło mi, że Profesor nigdy się na tym nie koncentrowała; wielka skromność sprawiała, że zsuwała te informacje gdzieś na margines wszelkich rozmów. Również w tak wydawałoby się wyczerpującym i wszechstronnym źródle, jakim jest Internet [Тарнашинська 2019], mоżna było odnaleźć szczątkowe informacje o Niej samej. Miałam jednak to szczęście, że mogłam zebrane dane zweryfikować u samego źródła, tzn. u prof. Andrusiw. Dziś Pani Profesor nie ma już między nami, jednak to zadanie wydaje mi się niezmiernie potrzebne, chociażby w kontekście pamięci o człowieku niezwykle wybitnym i zasłużonym. O takich ludziach - w moim przekonaniu - powinny mówić nie tyle cmentarze i nagrobki, ile przede wszystkim słowa w różnych (auto czy meta) konfiguracjach.

Prof. Stefania Andrusiw urodziła się 26 listopada 1942 roku w miejscowości Ripczyce koło Drohobycza na Ukrainie. W 1970 roku ukończyła studia filologiczne na Lwowskim Narodowym Uniwersytecie im. Iwana Franki ${ }^{1}$. Następnie, w 1987 roku, doktoryzowała się w Instytucie Literatury im. Tarasa Szewczenki Narodowej Akademii Nauk Ukrainy ${ }^{2}$. Kariera zawodowa, w tym

\footnotetext{
${ }^{1}$ Stefania Andrusiw przygotowała pracę magisterską na seminarium prowadzonym przez prof. Iwana Doroszenkę, jednego z pierwszych wykładowców i założycieli nowo powstałego wówczas wydziału dziennikarstwa.

${ }^{2}$ Już wówczas krystalizowały się pierwsze zainteresowania badawcze prof. Andrusiw. Przygotowana rozprawa pt.: Typologia ukraińskiej powieści historycznej II połowy XX wieku (na materiale twórczości Romana Iwanyczuka) oscylowała wokół zagadnień i na materiale prozy historycznej, co znalazło później swój wydźwięk w książce habilitacyjnej. Warto nadmienić, że kierownictwo czy oficjalną opiekę naukową sprawował prof. Mykoła Żułynski - wybitny literaturoznawca i badacz ukraiński.
} 
naukowa Stefanii Andrusiw rozwijała się w różnych ośrodkach naukowych: była współpracownikiem naukowym w lwowskim oddziale Instytutu Literatury im. T. Szewczenki NAN Ukrainy, pracowała na stanowisku starszego pracownika naukowego w Lwowskiej Galerii Sztuki, była zatrudniona na stanowisku wykładowcy literatury ukraińskiej we Lwowskim Instytucie RolnoGospodarczym. W 1993 roku rozpoczęła pracę w Lwowskim Narodowym Uniwersytecie im. I. Franki na stanowisku wykładowcy na wydziale dziennikarstwa, w powstałej w tym samym roku Katedrze Czasopiśmiennictwa Zagranicznego i Informacji. W 1996 roku uzyskała stopień doktora habilitowanego. Pierwszy kontakt z Polską prof. Andrusiw przypada na lata 90. W 1994 roku na zaproszenie UMCS w Lublinie prowadziła wykłady z historii literatury ukraińskiej w Instytucie Filologii Słowiańskiej. Jednocześnie nawiązała współpracę z Instytutem Filologii Słowiańskiej KUL i prof. Anną Woźniak ówczesnym dyrektorem slawistyki KUL-owskiej. Ta znajomość i współpraca przekształciły się w stałą pracę, bowiem w październiku 2001 roku Stefania Andrusiw otrzymała stanowisko profesora w Katedrze Literatur Wschodniosłowiańskich w Instytucie Filologii Słowiańskiej. W roku akad. 2005/2006 objęła kierownictwo nad powstałą Katedrą Literatury Ukraińskiej, które sprawowała do roku akad. 2012/2013 do czasu przejścia na emeryturę. Pomimo iż wróciła do swojego ukochanego Lwowa, to nadal utrzymywała kontakty naukowe z Instytutem i swoim lubelskim środowiskiem. Zakończyły się one jednak za wcześnie - w sierpniu 2018 roku pożegnaliśmy prof. Stefanię Andrusiw, której ciało spoczęło na Cmentarzu Łyczakowskim we Lwowie. Jednak nie zakończył się dialog naukowy z Jej bogatą spuścizną naukową, do której warto się odwoływać w poszukiwaniu nowych źródeł inspiracji. Ten fragment „lwowskiego tekstu” - tak pozwalam sobie określić dorobek naukowy Stefanii Andrusiw, jest ciągle aktualny badawczo i otwarty na dialog ze współczesnością.

Prof. Andrusiw należała do tego grona badaczy, których teksty świadczyły o nich samych, tj. o ich tożsamości, identyfikacji, światopoglądzie itp. Posiadała zdolność i jednocześnie lekkość łączenia faktów, myślenia w kluczu syntetycznym, postrzegania i interpretowania zjawisk w płaszczyźnie uniwersalnej, ogólnoludzkiej. Była odważną uczoną - nie bała się eksperymentować, poszukiwać nowych dróg interpretacji wśród najnowszych propozycji i metod badawczych. To faktycznie był umysł niczym niezniewolony, nie dający się zaszufladkować (wiekiem, pochodzeniem, doświadczeniem socrealizmu itp.). Zaproponowana tu próba przedstawienia Jej sylwetki naukowej nie ma charakteru wyczerpującego, bowiem nie opiera się ona na wszystkich tekstach Jej 
autorstwa. Jest to raczej fragment z całościowego portretu, w którym odwołuję się głównie do tekstów napisanych przez Panią Profesor w Lublinie.

Prof. Andrusiw w swoich badaniach, zwłaszcza tego lubelskiego okresu, obracała się - jeśli można się tak wyrazić - w kontekście najnowszych badań i metodologii. Jej teksty oscylowały wokół wrażliwości postmodernistycznej; interesowały ją badania w kluczu postkolonialnym, skoncentrowane, co jest zresztą naturalną konsekwencją, na kwestii tożsamości narodowej oraz jej nieodłącznym rewersie - inności [Skórczewski, 7]. Prezentowała postawę głęboko patriotyczną, dialogowo-patriotyczną, nigdy nacjonalistyczną. Była zwolenniczką dialogu polsko-ukraińskiego. Nigdy nie była bezkrytyczna wobec Ukrainy - jej przeszłości i współczesności. Właśnie dialog czy dyskurs to określenia, które często pojawiają się badaniach prof. Andrusiw. Taki właśnie format - format rozmowy ma błyskotliwa monografia Stefanii Andrusiw Modus natsional'noyi identychnosti: L'vivs'kyy tekst 30. rokiv XX st. [Андрусів 2000, 18-22], od której chciałabym rozpocząć charakterystykę Jej sylwetki naukowej. Wydana w 2000 roku książka, będąca efektem wieloletniej i intensywnej pracy Autorki, okazała się niezwykle ważnym elementem ukraińskich dyskusji tożsamościowych. Monografia od samego początku wywołała spore zainteresowanienie. Była to praca prowokacyjna, zmuszająca do dyskusji i refleksji - jak już na wstępie zaznaczył wybitny literaturoznawca ukraiński Mykoła Żułynski [Жулинський, 6]. Autorka prezentuje tekstowy świat Ukrainy Zachodniej lat 30. XX wieku, tzw. lwowski tekst - hipertekst, który z jednej strony jest już ukończony, bo zamknięty w pewnej przestrzeni czasowej, z drugiej, ciągle żywy, otwarty na dialog ze współczesnością. Uczona koncentruje się w swojej pracy nie na całym tekście lwowskim lat 30. Bierze na warsztat te jego teksty, które realizują się w gatunkach krzewiących tożsamość, chodzi mianowicie o prozę historyczną - historyczną beletrystykę, która aktywizuje historyczne aspekty tożsamości narodowej, bo traktuje o historii pewnym obrazie świata, pewnej historycznej, narodowej pamięci i jej rozwoju. Zresztą wybrany materiał - tzn. proza historyczna - nie jest przypadkowy, bo prof. Andrusiw była znana i rozpoznawana w literaturoznawstwie ukraińskim właśnie jako badacz prozy historycznej, krytyk, ze zdaniem którego liczono się, na opinię którego - jak zaznaczała Natalia Kolesnyczenko-Bratuń czekał z drżeniem serca nie jeden pisarz [Колесниченко-Братунь, 57]. Pani Profesor koncentrowała się w pracy na tzw. fenomenie galicyjskim, który postrzegała jako pewną zdolność czy właściwość, efektem której było zachowanie ukraińskiej tożsamości narodowej, przetrwanie Ukrainy i jej nadziei na odrębność i suwerenność, pomimo wielu klęsk, „polskiej okupacji”, prób wyna- 
rodowienia itp. [Андрусів 2000, 9]. Badaczka podkreślała znaczenie sztuki - literatury właśnie w obliczu zagrożenia. Literatura Ukrainy Zachodniej żyła - Jej zdaniem - dla jednego zadania - zachowania tożsamości narodowej [Андрусів 2000, 9]. Andrusiw zaznaczała, że kultura ukraińska lat 30. XX wieku, której przestrzeń została zawężona do Galicji i Lwowa, niczym Szecherezada opowiadała swoje historie w swoim języku, bojąc się jednocześnie zamilknąć [Андрусів 2000, 11]. Ten fenomen galicyjski - swego rodzaju „psychoterapeutyczne „laboratorium”, niezbędne do zachowania tożsamości narodowej [Андрусів 1997, 18] - Autorka starała się rozkodować, by następnie tą wiedzą podzielić się czy przenieść ją w perspektywę całej Ukrainy.

Działalność naukowa prof. Andrusiw w Polsce również oscylowała wokół kwestii świadomości narodowej. Badaczka odeszła jednak od prozy historycznej w stronę cieszącej się coraz większą popularnością i uznaniem, nie tylko na Ukrainie, współczesnej prozy ukraińskiej i jej autorów. Coraz częściej i chętniej wykorzystywała najnowsze propozycje badawcze, w tym instrumentarium postmodernistyczne, teorię intertekstualności, narratologię, antropologię oraz bardzo aktywnie posługiwała się krytyką postkolonialną. Warto w tym miejscu podkreślić, że zainteresowanie współczesnością nie przysłoniło uwagi do tzw. kanonu literatury ukraińskiej. Pani Profesor zawsze żywo reagowała czy opisywała stan i kondycję literaturoznawstwa ukraińskiego, którego sama była reprezentantką. Nie było to jednak ślepe przywiązanie, nigdy nie gloryfikowała stanu literaturoznawstwa ukraińskiego, potrafiła zachować $\mathrm{z}$ jednej strony zaangażowanie, $\mathrm{z}$ drugiej - o ile to możliwe - zdrowy dystans [Андрусів 2004, 48-53]. Zdaniem prof. Andrusiw konflikt stare - nowe, kolonialne - postkolonialne, który można zaobserwować w literaturoznawstwie ukraińskim, jest próbą rozgraniczenia i zaszufladkowania czegoś, co takiemu działaniu się nie poddaje. Ubolewała nad brakiem dialogu między pokoleniami, agresją młodych, ironią, kpiną i dekonstrukcją. Andrusiw zaznaczała, że śmiech i ironia mają wielką funkcję terapeutyczną, ale nie mogą być postrzegane i uprawiane jako totalne i jedyne formy dialogu z tradycją i jej „ocalałymi przedstawicielami” [Андрусів 2004, 49]. Do tej kwestii wróciła raz jeszcze 10 lat później, jednak - jak się okazuje - nie zaszły tu rewolucyjne zmiany: literaturoznawstwo ukraińskie - jak sygnalizuje Autorka tekstów - już w samym tytule - pozostaje w sytuacji nieustającego „między” [Андрусів 2013, 58-68]. Zaprezentowany tu obraz zyskał nowe perspektywy - głównie postkolonialną. Badaczka interpretuje stan współczesnego literaturoznawstwa ukraińskiego właśnie z punktu widzenia studiów postkolonialnych, starając się wskazać przyczyny i działania, które do tego doprowadziły. Podkreśla, że po 
1991 roku przed uczonymi ukraińskimi stanęło niezwykle trudne zadanie - po końcu nauki stworzyć naukę od nowa [Андрусів 2013, 65]. W tej kwestii dzieje się wiele - jak zaznacza Autorka - jednak daleko jeszcze do ideału [Андрусів 2013, 62 n.]. Przymusowy radziecki post metodologiczny - jak zaznacza Uczona - spowodował poważną konsekwencję, z którą musi mierzyć się współczesne literaturoznawstwo ukraińskie, a mianowicie fakt, że w wyniku tego postu tłumaczenia wielu ważnych tekstów literaturoznawczych pojawiają się na Ukrainie z bardzo przesuniętą perspektywą czasową, co ma duże znaczenie, bo budowana w ten sposób przestrzeń literaturoznawcza jest nielogiczna, nie ma procesu, następstwa, relacji wpływu itd. [Андрусів 2010 (a), 5-8]. W tym kontekście prof. Andrusiw wskazuje na „pozornie nową” teorię antropologię, która wywołała spore zainteresowanie w literaturoznawstwie ukraińskim (i nie tylko). Uważa, że antropologia nie jest nową metodą; w Jej przekonaniu, jest to jedynie transdyscyplinarna forma poszerzenia literaturoznawstwa o antropologiczną wrażliwość, dzięki której wyraźniej uwidaczniają się problemy życia ludzkiego [Андрусів 2010 (a), 5-8].

Problem dotyczący tożsamości oraz jej konfrontacji z Innością analizuje Profesor m.in. w tekście Sebe pobachyty yak v lyustri. Deshcho pro antropolohichnu pryrodu transkordonnykh peremishchen' [Андрусів 2010 (c), 155167]. Podkreśla tu znaczenie dwóch kategorii - czasu i przestrzeni jako elementów konstruujących tożsamość zarówno w wymiarze indywidualnym, jak i zbiorowym. Omawiając kategorię przestrzeni zwraca uwagę na kwestię granicy wyznaczającej odrębność my - oni. Przekraczanie tej granicy - podróżowanie to nie tylko poznawanie innych, ale też pokazanie siebie innym, konfrontowanie się z nim. W tej konfrontacji wzmacniamy poczucie własnej tożsamości i odrębności, jednocześnie jest to ciągłe poznawanie Innego, pokonywanie obcości, podejrzliwości do obcego, Innego, wzajemnych uprzedzeń i stereotypów. Właśnie na takim tle Autorka omawia kwestię stosunków polsko-ukraińskich. Widzi potrzebę dialogu nie na poziomie deklaracji państwowych, międzyrządowych uzgodnień dotyczących wspólnej pokojowej polityki, ale raczej na poziomie pojedynczych relacji międzyludzkich - wspólnych rozmów, modlitw, życia. Te słowa Stefanii Andrusiw nie były tylko teoretycznym wywodem, bowiem ten dialog realizowała Ona swoim życiem. Kiedy wspominam Panią Profesor w tym kontekście, to staje mi przed oczyma nie tylko osoba, która żyła razem z nami, żyła naszymi problemami, ale również, a może przede wszystkim razem z nami płakała i modliła się - jak wówczas, gdy odchodził papież Jan Paweł II, czy podczas Mszy św. żałobnej za ofiary katastrofy smoleńskiej. 
Rozważania na temat przesunięć w przestrzeni, dystansu oraz perspektywy, którą uzyskujemy dzięki podróży, odnajdujemy również w tekście Prostorova chutlyvist' snchasnoyi yevropeys 'koyi kul'tury [Андрусів 2010 (b), 253-262]. Żyć - to dla Uczonej - semiotyzować przestrzeń, uporządkować ją, podporządkować [Андрусів 2010 (b), 253]. Tym, co przestrzeń porządkuje najpełniej, jest wspomniana już granica, która jest jednocześnie przejściem, miejscem dialogu, nie zawsze równego z równym, zwłaszcza jeśli chodzi o granice między państwami. W centrum uwagi Badaczki znalazł się tu cykl esejów poświęconych znikającym miejscom na terenie całej Europy - Znikajaca Europa, które uczyniła punktem odniesienia dla rozważań na temat przestrzeni, miejsca, konfrontacji z pamięcią i historią.

W duchu imagologii, rozważań nad innością w perspektywie studiów postkolonialnych utrzymany jest artykuł Relacje polsko-ukraińskie z perspektywy postcolonial studies [Андрусів 2011, 61-69]. Charakteryzując kulturę ukraińską jako skolonizowaną, Autorka zwraca uwagę na możliwości, jakie dają coraz popularniejsze studia postkolonialne w odczytaniu tejże literatury [AHдрусів 2011, 61-62]. Podkreśla specyfikę odczytania postkolonialnego: uważnego i podejrzliwego, ze zwróceniem uwagi na to, kto mówi, co mówi i jak mówi. Jako przykład do zastosowania takiego odczytania wykorzystuje esej Pawła Laufera $O$ Ukrainie z pobocza, a czasem i z rowu, czyniąc zeń przykład takiego właśnie, zwierzchniego stosunku wobec Ukrainy i jej kultury, podobny do tego, który prezentuje Polak - celnik wkraczający do autobusu wypełnionego Ukraińcami, opisany przez Jurija Andruchowycza w eseju Misce zustrichi-Germashka.

Problematyki tożsamościowej dotyczy również artykuł Totalitaryzm i kul'tura: ukrayins'kyy dosvid dukhovnoho samozberezhennya [Андрусів 2006 (b), 105114]. Prof. Andrusiw zwraca tu uwagę, zresztą nie po raz pierwszy, na kwestię pewnego rozdwojenia jaźni - podwójnej tożsamości ludzi wobec totalitaryzmu i kolonializmu. $Z$ jednej strony, na zewnątrz, prezentują oni lojalność i uległość, z drugiej, wewnętrznie, wrogość do systemu totalitarnego [Андрусів 2006 (b), 114], a wszystko po to, by przetrwać i zachować swoją tożsamość. Podobne zjawisko obserwuje Uczona w przestrzeni religii - tradycji chrześcijańskiej na Ukrainie [Андрусів 2008 (c), 209-219], która znalazła się w zagrożonym położeniu, będąc konsekwentnie zwalczana zwłaszcza na początku XX w., kiedy ateizm zlał sie w jedno z marksizmem, a następnie leninizmem, przekształcając się z teorii w praktykę społeczną, zyskując status wojującego ateizmu. Tu podobnie zauważa Autorka tzw. dwie twarze - dwie postawy ludzi, którzy na zewnątrz byli ateistami, a wewnątrz - ludźmi wierzącymi. Z tą tylko 
istotną różnicą, że taki stan rzeczy nie mógł trwać długo, bo - jak uważa - ten zewnętrzny, „udawany” ateizm niszczył, unicestwiał wewnętrzną duchowość, zmieniał psychikę zwłaszcza młodych ludzi, na zawsze wykreślając ich z tradycji chrześcijańskiej [Андрусів 2008 (c), 211]. Także w tym wypadku Badaczka dostarcza literackich przykładów tego stanu rzeczy, bo literatura zawsze - jak zaznacza - czuła jak sejsmograf reagowała na wszelkie zmiany. Kiedy upadł komunizm wydawałoby się, że zwycięstwo chrześcijaństwa jest jednoznaczne. Jak się okazuje - nie do końca tak jest, ateizm poczynił tak mocne zmiany, z którymi - jak podkreśla prof. Andrusiw - Ukraina ciągle się zmaga. Jej zdaniem odbudowano świat chrześcijański na Ukrainie, ale tylko powierzchownie. Degradacja społeczeństwa trwa i te tematy porusza najnowsza literatura ukraińska [Андрусів 2008 (c), 218 n.].

Prof. Andrusiw zwracała również uwagę na wrażliwość postmodernistyczną; to zainteresowanie przebija $\mathrm{z}$ wielu tekstów. Warto w tym miejscu wymienić chociażby artykuł Tsytuvannya “real'nosti" $v$ ukrayins'komu literaturnoти postmodernizmi [Андрусів 2006 (a), 221-231], w którym dokonuje Ona interpretacji współczesnej literatury ukraińskiej (m.in. powieść Jurija Andruchowycza, Dwanaście kręgów) z zastosowaniem intertekstualnego instrumentarium, wskazując na wszechobecne cytowanie - grę, ironię, parodię, mające na celu reanimację literatury dawnej [Андрусів 2006 (a), 225]. W prowadzonej na Ukrainie dyskusji czy sporze o możliwość zaistnienia postmodernizmu w nie do końca industrialnym kraju, nigdy nie podawała tego faktu w wątpliwość; kiedy inni się sprzeczali i dyskutowali, Ona odczytywała teksty właście w duchu i z perspektywy postmodernistycznej, którą - jak w cytowanym artykule - uznawała za współczesny „neohumanizm” [Андрусів 2006 (a), 231]. Podobne zagadnienia porusza również tekst Tsytuvannya $v$ intertekstual'niy hri literatury z masovoyи kul'turoуи [Андрусів 2009 (b), 3-7].

$\mathrm{Na}$ temat miejsca, koncepcji, wręcz interpretacji gry z historią we współczesnej literaturze czytamy w artykule Postmodernists'ka kontseptsiya istoriyi $i$ suchasna ukrayins'ka proza [Андрусів 2008 (d), 97-105]. Posługując się utworami wspomnianego już Jurija Andruchowycza oraz Wasyla Kożelanki Stefania Andrusiw dokonuje prezentacji ponowoczesnej koncepcji historii, która w ujęciu literatury jawi się raczej jako forma narracji o historii, prezentowana w różnych autorskich odsłonach - koncepcjach.

Uwagę Uczonej zajmowała również pozycja i charakterystyka bohatera we współczesnej prozie ukraińskiej. Na ten temat czytamy w artykule Heroy suchasnoyi ukrayins'koyi prozy: Vyprobuvannya Yevropoyи [Андрусів 2008 (b), 125-136]. Autorka pisze o tzw. sytuacji próby, którą jest dla bohatera współ- 
czesnej prozy ukraińskiej spotkanie z Europą. Ten temat - jak zaznacza Stefania Andrusiw - jest dość często eksploatowany przez samych współczesnych pisarzy ukraińskich, bo i oni często są tymi bohaterami [Андрусів 2008 (b), 126]. Podróżując po Europie, sami stają się wizytówką Ukrainy. W tej próbie, jak zauważa Badaczka, bohaterowie wypadają wyjątkowo dobrze: są to postacie bez kompleksów, bez poczucia mniejszej wartości, bez braków językowych, to inteligenci nieodczuwający strachu przed Europą, którą „zdobywają”, jednocześnie prezentując jej swój, ukraiński palimpsest kulturowy, poszerzając tym samym Europę o Ukrainę [Андрусів 2008 (b), 131 n.].

Pozostający w kontekście rozważań nad tożsamością ukraińską i procesem jej kształtowania jest artykuł Stefanii Andrusiw Antropolohiya prostoru $v$ ukrayins'kiy dylohiyi Mykoly Hoholya (Vechera na khutore bliz Dikan'ki, Mirgorod) [Андрусів 2009 (a), 41-51). Zawarte tu rozważania wpisują się we wciąż trwającą dyskusję, dotyczacą przynależności Gogola, jego tożsamości. Sam pisarz stanowi dla Ukraińców trudną kwestię, bo ciągle przypominającą o skomplikowanym i niezakończonym procesie kształtowania się tożsamości ukraińskiej, wyodrębniania jej od rosyjskiej. Gogol - można powiedzieć - to naoczny dowód kolonializmu, który służył jako broń przeciwko ruchowi ukraińskiemu [Riabczuk, 104-105]. We wspomnianym tekście Stefania Andrusiw również nawiązuje do tej tożsamościowej dyskusji, wojny tożsamości w świadomości Gogola; podkreśla dominujące dla twórczości Gogola znaczenie ukraińskiej matrycy, obecnej - jak zaznacza - we wszystkich utworach pisarza, zachowaniu, sposobie myślenia, mówienia, odczuwania itp. [Андрусів 2009 (a), 47 n.].

Godny uwagi, acz pozornie odbiegający od prowadzonych kierunków badań jest tekst Morfolohiya kazky V. Proppa v metodolohichnomu konteksti [Андрусів 2008 (a), 5-8]. Andrusiw analizuje w nim chyba najważniejszą pracę tego genialnego uczonego - Morfologię bajki, na tle całej twórczości Proppa, która - Jej zdaniem - wyprzedzała swój czas, jednocześnie stworzyła filary dla kilku metodologii XX i XXI wieku.

Jedną z ostatnich inicjatyw naukowych prof. Andrusiw była organizacja cyklu spotkań - seminariów naukowych poświęconych twórczości pisarki ukraińskiej Łesi Ukrainki. Tę inicjatywę, należącą do rzadkości w polskiej slawistyce, udało się kontynuować już po przejściu Pani Profesor na naukową emeryturę. Chociaż twórczość pisarki ukraińskiej przełomu XIX i XX wieku nie stanowiła centrum zainteresowań badawczych Stefanii Andrusiw, to zawsze chętnie pochylała się nad tą niezwykle ważną postacią w kulturze ukraińskiej. W duchu aktywnie wykorzystywanej problematyki tożsamości Uczona 
prezentuje proces krystalizowania się tożsamości twórczej i narodowej Łesi Ukrainki, o czym czytamy w artykule Konstruyuvannya identychnostey u zhyttyetvorchosti Lesi Ukrayinky. Postkolonial'na perspektyva [Андрусів 2012, 2437]. Pisarka ukraińska - jak zaznacza Andrusiw - należała do tego grona przedstawicieli społeczeństwa ukraińskiego, które w nieistniejącym języku starało się prezentować zarówno językową, jak i kulturową odrębność Ukrainy, tworząc tym samym dyskurs antykolonialny. Taką właśnie pozycję w literaturze i kulturze ukraińskiej zajmowała Łesia Ukrainka, na której już od najmłodszych lat ciążył gorset obowiązku - bycia w literaturze przede wszystkim Ukrainką, pisarką, dopiero później kobietą, siostrą, córką itp. [Андрусів 2012, 28 n.].

Podsumowując powyższe rozważania, warto jeszcze raz podkreślić, że profesor Stefania Andrusiw zapisała się w literaturoznawstwie i naszej pamięci jako wybitna i niezwykle wszechstronna Uczona, pasjonatka literatury ukraińskiej, obeznana z wieloma metodologiami współczesnego literaturoznawstwa. Była wielką patriotką Ukrainy, pochłoniętą sprawami jej przeszłości, teraźniejszości i przyszłości. Była wielkim przyjacielem Polski, zaangażowanym w dialog i porozumienie polsko-ukraińskie. Wreszcie była człowiekiem, którego już nam niezmiernie brakuje...

\section{BIBLIOGRAFIA}

Андрусів, Стефанія. (а). „Антропологія літератури - літературна антропологія - літературознавча антропологія (до семантики терміна)”. Науковий вісник Волинського національного університету ім. Лесі України. Філологічні науки. 11 (2010): 5-8 [Andrusiv, Stefaniya. (a). „Antropolohiya literatury - literaturna antropolohiya - literaturoznavcha antropolohiya (do semantyky termina)". Naukovyy visnyk Volyns'koho natsional'noho universytetu im. Lesi Ukrayinky. 11 (2010): 5-8].

Андрусів, Стефанія. (а). „Антропологія простору в українській дилогії Миколи Гоголя (Вечера на хуторе близ Диканьки, Миргород)”. Roczniki Humanistyczne. 57 (2009). 7 : 41-51 [Andrusiv, Stefaniya. (a). „Antropolohiya prostoru v ukrayins'kiy dylohiyi Mykoly Hoholya (Vechera na khutore bliz Dikan'ki, Mirgorod)". Roczniki Humanistyczne. 57 (2009). 7: 41-51].

Андрусів, Стефанія. (а). „Морфологія казки В. Проппа в методологічному контексті”. Науковий вісник Волинського національного університету ім. Лесі України. Філологічні науки. 8 (2008): 5-8 [Andrusiv, Stefaniya. (a). „, Morfolohiya kazky V. Proppa v metodolohichnomu konteksti”. Naukovyy visnyk Volyns'koho natsional'noho universytetu im. Lesi Ukrayinky. 8(2008): 5-8].

Андрусів, Стефанія. (а). „Цитування «реальності» в українському літературному постмодернізмі”. Intertekstualność w literaturach i kulturach słowiańskich. Ed. I. Kowalska-Paszt et al. Szczecin, 2006. 221-231 [Andrusiv, Stefaniya. (a). „Tsytuvannya “real'nosti” v ukra- 
yins'komu literaturnomu postmodernizmi". Intertekstualność w literaturach i kulturach słowiańskich, Ed. I. Kowalska-Paszt et al. Szczecin, 2006. 221-231].

Андрусів, Стефанія. (b). „Герой сучасної української прози: випробування Європою”. Волинь філологічна. Текст і контекст. Польська, українська, білоруська та російська література в європейському контексті. Вип. 6. Ч. 1. Луцьк, 2008. 125-139 [Andrusiv, Stefaniya. (b). „Heroy suchasnoyi ukrayins'koyi prozy: Vyprobuvannya Yevropoyu”. Volyn’ filolohichna. Tekst i kontekst. Pol's'ka, ukrayins'ka, bilorus'ka, ta rosiys'ka literatura v yevropeys'komu konteksti. Vyp. 6. Ch. 1. Luts'k, 2008. 125-139].

Андрусів, Стефанія. (b). „Просторова чутливість снчасної європейської культури”. Z lubelskich badań nad Słowiańszczyzną Wschodnią. Księga dedykowana profesorowi Michałowi Łesiowowi. Ed. D. Nowacka et al. Lublin: Wydawnictwo KUL, 2010. 253-262 [Andrusiv, Stefaniya. (b). „Prostorova chutlyvist' snchasnoyi yevropeys'koyi kul'tury”. Z lubelskich badań nad Słowiańszczyzną Wschodnią. Księga dedykowana profesorowi Michałowi Łesiowowi. Ed. D. Nowacka et al. Lublin: Wydawnictwo KUL, 2010. 253-262].

Андрусів, Стефанія. (b). „Тоталітаризм і культура: український досвід духовного самозбереження”. Wschód i Zachód: w poszukiwaniu Europy duchowej. Ed. M. OłdakowskaKuflowa et al. Lublin:TN KUL, 2006. 105-114 [Andrusiv, Stefaniya. (b). „Totalitaryzm i kul'tura: ukrayins'kyy dosvid dukhovnoho samozberezhennya”. Wschód i Zachód: w poszukiwaniu Europy duchowej. Ed. M. Ołdakowska-Kuflowa et al. Lublin:TN KUL, 2006. 105-114].

Андрусів, Стефанія. (b). „Цитування в інтертекстуальній грі літератури з масовою культурою”. Науковий вісник Волинського національного університету ім. Лесі України. Філологічні науки. 12 (2009): 3-7 [Andrusiv, Stefaniya. (b). „Tsytuvannya v intertekstual'niy hri literatury z masovoyu kul'turoyu". Naukovyy visnyk Volyns'koho natsional'noho universytetu im. Lesi Ukrayinky. 12 (2009): 3-7].

Андрусів, Стефанія. (c). „Себе побачити як в люстрі. Дещо про антропологічну природу транскордонних переміщень”. Między Wschodem a Zachodem. Z dziejów kultury pogranicza polsko-wschodniosłowiańskiego. Ed. W. Kołbuk et al. Lublin: Wydawnictwo KUL, 2010. 155-167 [Andrusiv, Stefaniya. „Sebe pobachyty yak v lyustri. Deshcho pro antropolohichnu pryrodu transkordonnykh peremishchen"'. Między Wschodem a Zachodem. Z dziejów kultury pogranicza polsko-wschodniosłowiańskiego. Ed. W. Kołbuk et al. Lublin: Wydawnictwo KUL, 2010. 155-167].

Андрусів, Стефанія. (с). „Українська христянська традиція contra совєтський атеїзм: реакція художньої літератури”. Poznawanie sąsiadów. Z zagadnień religijnych w polskiej i ukraińskiej kulturze. Ed. M. Ołdakowska-Kuflowa, M. Kawecka. Lublin: TN KUL, 2008. 209-219 [Andrusiv, Stefaniya. (c). „Ukrayins'ka khrystyans'ka tradytsiya contra sovyets'kyy ateyizm: reaktsiya khudozhn'oyi literatury”. Poznawanie sąsiadów. Z zagadnień religijnych w polskiej i ukraińskiej kulturze. Ed. M. Ołdakowska-Kuflowa, M. Kawecka. Lublin:TN KUL, 2008. 209-219].

Андрусів, Стефанія. (d). „Постмодерністська концепція історії і сучасна українська проза”. Wokół problemów Historii. Studia o kulturze i literaturach wschodniosłowiańskich. Ed. A. Woźniak. Lublin: TN KUL, 2008. 97-105 [Andrusiv, Stefaniya. „Postmodernists'ka kontseptsiya istoriyi i suchasna ukrayins'ka proza”. Wokół problemów Historii. Studia o kulturze i literaturach wschodniosłowiańskich. Ed. A. Woźniak. Lublin: TN KUL, 2008. 97-105]. 
Андрусів, Стефанія. „Конструювання ідентичностей у життєтворчості Лесі Українки. Постколоніальна перспектива”. Roczniki Humanistyczne. 60 (2012). 7: 24-37 [Andrusiv, Stefaniya. „Konstruyuvannya identychnostey u zhyttyetvorchosti Lesi Ukrayinky. Postkolonial'na perspektyva”. Roczniki Humanistyczne. 60 (2012). 7: 24-37].

Андрусів, Стефанія. „, Проблеми національної ідентичності”. Слово і Час. 3 (1997): 18-22 [Andrusiv, Stefaniya. ,,Problemy natsional'noyi identychnosti”. Slovo i Chas. 3 (1997): 18-22].

Андрусів, Стефанія. „Сучасне українське літературознавство: тексти і контексти”. Слово i Чac. 5 (2004): 48-53 [Andrusiv, Stefaniya. „Suchasne ukrayins'ke literaturoznavstvo: teksty i konteksty". Slovo i Chas. 5 (2004). 48-53].

Андрусів, Стефанія. Модус національної ідентичності: Львівський текст $30-$ х років XX ст. Львів-Тернопіль: Нац. ун-т ім. І. Франка; Дружба, 2000 [Andrusiv, Stefaniya. Mоdus natsional'noyi identychnosti: L'vivs'kyy tekst 30. rokiv XX st. L'viv-Ternopil': Nac. Un-t im. I. Franka; Druzhba, 2000].

Жулинський, Микола. Культурологічний дискурс Галичини. Андрусів Стефанія. Модус національної ідентичності: Львівський текст 30-х років ХХ ст. Львів: Нац. ун-т ім. I. Франка. Тернопіль: Дружба, 2000. 5-7 [Zhulyns'kyy, Mykola. Kul'turolohichnyy dyskurs Halychyny. Stefaniya Andrusiv. Modus natsional'noyi identychnosti: L'vivs'kyy tekst 30. rokiv XX st. L'viv: Nats. Un-t im. I. Franka. Ternopil': Druzhba, 2000. 5-7].

Колесниченко-Братунь, Наталія. „Книжка Стефанії Андрусів: ще раз про модус національної ідентичності”. Слово і Час. 7 (2001): 57 [Kolesnychenko-Bratun', Nataliya. „Knyzhka Stefaniyi Andrusiv: shche raz pro Modus natsional'noyi identychnosti”. Slovo i Chas. 7 (2001): 57].

Тарнашинська. Людмила, Андрусів Стефанія Миколаївна. Енциклопедія сучасної України. http://esu.com.ua/search_articles.php?id=44269 [доступ: 15.06.2019] [Tarnashyns'ka, Lydmyla. Andrusiv Stefaniya Mykolayivna. Entsyklopediya suchasnoyi Ukrayiny. http://esu.com.ua/search_articles.php?id=44269 [dostup: 15.06.2019]].

Andrusiw, Stefania. „Relacje polsko-ukraińskie z perspektywy postcolonial studies”. Roczniki Humanistyczne. 59 (2011) 7: 61-69.

Andrusiw, Stefania. „Współczesne lietraturoznawstwo ukraińskie: sytuacja nieustającego «między»". Teka Komisji Polsko-Ukraińskich Związków Kulturowych. Oddział PAN w Lublinie. T. 7. Lublin, 2013. 58-68.

Kaczmarczyk, Marta. „Andrusiw Stefania”. Encyklopedia 100-lecia KUL. T. 1. Lublin: Wydawnictwo KUL, 2018. 14.

Skórczewski, Dariusz. Teoria - literatura - dyskurs. Pejzaż postkolonialny. Lublin: Wydawnictwo KUL, 2013.

Riabczuk, Mykoła. Gogol i wojna tożsamości. M. Riabczuk, Ukraina. Syndrom postkolonialny, Wrocław-Wojnowice, 2015. 104-105. 


\section{UMYSŁ NIE ZNIEWOLONY. \\ O ZAINTERESOWANIACH NAUKOWYCH PROFESOR STEFANII ANDRUSIW}

\section{Streszczenie}

Artykuł prezentuje sylwetkę naukowo-badawczą profesor Stefanii Andrusiw, ze szczególnym zwróceniem uwagi na główne kierunki badań oraz działalność dydaktyczną prowadzoną w Polsce.

Słowa kluczowe: profesor Stefania Andrusiw; ukraińskie literaturoznawstwo; literatura ukraińska.

NON-CAPTIVE MIND.

PROF. STEFANIA ANDRUSIV'S SCIENTIFIC INTERESTS

S u m m a r y

The article presents scientific profile and didactic achievements of Professor Stefania Andrusiw, during her fruitful work at The John Paul II Catholic University of Lublin.

Key words: Professor Stefania Andrusiw; Ukrainian literary studies; Ukrainian literature. 